\title{
Komuniti Pembelajaran Profesional di Sekolah Menengah Kebangsaan di Malaysia
}

\section{(Professional Learning Community in Malaysian National Secondary Schools)}

\author{
Azura Pun ${ }^{*}$ (D), Mahaliza Mansor² \\ ${ }^{1}$ Fakulti Pengurusan dan Ekonomi, Universiti Pendidikan Sultan Idris (UPSI), Perak, Malaysia. \\ Email: azuraailinnizzuan@gmail.com \\ ${ }^{2}$ Fakulti Pengurusan dan Ekonomi, Universiti Pendidikan Sultan Idris (UPSI), Perak, Malaysia. \\ Email: mahaliza@fpe.upsi.edu.my
}

\section{CORRESPONDING \\ AUTHOR (*): \\ Azura Pun \\ (azuraailinnizzuan@gmail.com)}

KATA KUNCI:

Komuniti Pembelajaran

Profesional

Sekolah Menengah Kebangsaan

Penambahbaikan sekolah

\section{KEYWORDS:}

Professional Learning

Community

National Secondary School

School improvement

\section{CITATION:}

Azura Pun \& Mahaliza Mansor. (2022)

Komuniti Pembelajaran Profesional di

Sekolah Menengah Kebangsaan di Malaysia.

Malaysian Journal of Social Sciences and

Humanities (MJSSH), 7(2), e001287.

https://doi.org/10.47405/mjssh.v7i2.1287

\begin{abstract}
ABSTRAK
Kajian ini bertujuan mengenal pasti tahap Komuniti Pembelajaran Profesional dan mengenal pasti tahap setiap dimensi Komuniti Pembelajaran Profesional di sekolah menengah kebangsaan di Malaysia. Kajian ini menggunakan pendekatan kuantitatif yang melibatkan seramai 702 orang guru sekolah menengah kebangsaan di Malaysia. Kaedah persampelan berstrata tidak berkadaran telah digunakan dalam pemilihan sampel. Dapatan kajian menunjukkan bahawa guru-guru sekolah menengah kebangsaan di Malaysia telah mengamalkan Komuniti Pembelajaran Profesional pada tahap yang tinggi. Setiap dimensi Komuniti Pembelajaran Profesional secara keseluruhannya juga berada pada tahap skor min yang tinggi. Kesimpulannya pengamalan Komuniti Pembelajaran Profesional oleh guruguru menunjukkan mereka komited dalam melaksanakan pelbagai program penambahbaikan demi meningkatkan pencapaian murid dan prestasi sekolah.
\end{abstract}

\section{ABSTRACT}

This study aims to identify the level of Professional Learning Community Practice and the level of each dimension of Professional Learning Community among teachers in national secondary schools in Malaysia. This study uses a quantitative approach involving a total of 702 national secondary school teachers in Malaysia. Disproportionate stratified sampling method was used in sample selection. The findings of the study show that national secondary school teachers in Malaysia have adopted a Professional Learning Community at a high level. Each dimension of the Professional Learning Community as a whole is also at a high mean frequency level. In conclusion, the practice of Professional Learning Community by teachers shows that they are committed in implementing various improvement programs in order to improve student achievement and school performance. 
Sumbangan/Keaslian: Kajian ini menyumbang kepada literatur sedia ada berkaitan tahap Komuniti Pembelajaran Profesional di Malaysia khususnya di sekolah menengah kebangsaan. Tambahan pula, instrumen Komuniti Pembelajaran Profesional yang digunakan dalam kajian ini dibangunkan berdasarkan konteks tempatan. Lapan komponen utama yang mengandungi 44 item mengukur secara terperinci pelbagai aspek berkaitan Komuniti Pembelajaran Profesional.

\section{Pengenalan}

Komuniti Pembelajaran Profesional merupakan budaya pembelajaran yang memerlukan komuniti sekolah belajar secara kolaboratif demi menjana pengetahuan dan berkongsi maklumat bagi meningkatkan kecemerlangan murid (Tai \& Omar, 2019). Menurut Stoll et al. (2006), Komuniti Pembelajaran Profesional dirujuk pada komuniti yang berkongsi dan berbincang secara kritis amalan mereka secara berterusan, reflektif, kolaboratif, inklusif, berorientasikan pembelajaran dan menggalakkan perkembangan secara menyeluruh. Selain itu, Komuniti Pembelajaran Profesional juga merupakan usaha kolektif individu mahupun kumpulan yang mahu bekerja secara kolaboratif untuk meningkatkan pencapaian terbaik murid (Toole \& Louise, 2002; Mitchell \& Sackney, 2000; King \& Newmann, 2001).

Selain itu, menurut Dufour, Dufour, Eaker dan Many (2006), Komuniti Pembelajaran Profesional adalah usaha para pendidik yang bekerja secara kolaboratif, komited dan berterusan untuk membuat inkuiri serta kajian tindakan bagi mencapai prestasi yang lebih baik untuk pelajar mereka. Komuniti Pembelajaran Profesional telah mula diperkenalkan di Malaysia pada tahun 2011. Oleh itu, dalam membuat penstrukturan semula sekolah, penekanan harus diberikan terhadap Komuniti Pembelajaran Profesional untuk membentuk profesionalisme guru (Louis, Marks, \& Kruse, 1996). Malahan, Lomos, Hofman dan Bosker (2011) serta Zhang dan Sun (2019), turut menegaskan bahawa pengamalan Komuniti Pembelajaran Profesional akan memberi impak terhadap reformasi sekolah, pembangunan guru dan pembelajaran murid.

Malahan, pada peringkat awal kajian, Komuniti Pembelajaran Profesional banyak dipengaruhi oleh konsep pembangunan organisasi pembelajaran yang diperkenalkan oleh Senge (1990). Pada tahun 1997, Hord (1997)mengambil inisiatif untuk membuat adaptasi idea tersebut dan membentuk model baharu yang memberi gambaran yang jelas kepada pengetua dan guru tentang perubahan dalam budaya pembelajaran sepanjang hayat di sekolah. Kajian berkaitan Komuniti Pembelajaran Profesional berkembang luas di negara Barat dan semakin mendapat perhatian di negara-negara Asia termasuk Malaysia. Sebagai sebuah negara yang sedang giat melakukan transformasi dalam sistem pendidikan, Malaysia telah turut serta dalam pembudayaan Komuniti Pembelajaran Profesional.

Walaupun Kementerian Pendidikan Malaysia telah memperkenalkan Komuniti Pembelajaran Profesional pada tahun 2009 di Malaysia, namun kajian tentang Komuniti Pembelajaran Profesional yang dijalankan oleh Kareem et al. (2019) di sekolah menengah harian dan sekolah menengah kebangsaan agama menunjukkan tahap Komuniti Pembelajaran Profesional di sekolah menengah di Semenanjung Malaysia hanya mencapai tahap 'agak baik' sahaja. Kementerian Pendidikan Malaysia secara khususnya telah menyasarkan transformasi budaya kecemerlangan profesionalisme berasaskan 
rakan setugas melalui pembangunan Komuniti Pembelajaran Profesional dan sasaran pelaksanaan ialah melalui gelombang ketiga Pelan Pembangunan Pendidikan Malaysia bermula 2021-2025 (Kementerian Pendidikan Malaysia, 2012).

\section{Sorotan Literatur}

Di Malaysia, program Komuniti Pembelajaran Profesional telah dilaksanakan dalam kalangan guru di sekolah-sekolah pada tahun 2011 (Kementerian Pendidikan Malaysia, 2014) dan kini pelaksanaannya telah merangkumi semua sekolah di seluruh Malaysia. Sebagai tanda sokongan terhadap pelaksanaan Komuniti Pembelajaran Profesional, Kementerian Pendidikan Malaysia telah mengiktiraf Komuniti Pembelajaran Profesional dalam Pelan Pembangunan Pendidikan Malaysia (PPPM) 2013-2025 sebagai satu reformasi pendidikan untuk menggalakkan kerjasama dalam kalangan guru untuk meningkatkan kualiti pengajaran dan pembelajaran. Dalam usaha untuk mencapai visi, Kementerian Pendidikan Malaysia (2015) menegaskan aktiviti Komuniti Pembelajaran Profesional yang dilaksanakan adalah seperti perkongsian pengetahuan dan kepakaran, kerja berpasukan dan kerjasama.

Kajian terhadap Komuniti Pembelajaran Profesional giat dijalankan di Malaysia sejak tahun 2009. Menurut Zuraidah (2010), pengamalan Komuniti Pembelajaran Profesional memberi gambaran tentang pelibatan secara langsung guru-guru di sekolah dalam membentuk budaya kolaboratif dalam pasukan, membangunkan visi, misi, nilai dan matlamat di sekolah. Seterusnya, usaha-usaha yang memberi tumpuan pada pembelajaran, kepimpinan, perancangan untuk menambah baik sekolah, meraikan kejayaan dan melakukan perubahan bagi memperkasakan visi dan misi sekolah berlandaskan perkongsian bersama (Zuraidah, 2010). Malahan, menjelaskan bahawa kebanyakan sekolah di Malaysia mempunyai kesediaan yang tinggi dalam meningkatkan pelaksanaan Komuniti Pembelajaran Profesional di Malaysia. Tambahan pula, Komuniti Pembelajaran Profesional mendapat mandat daripada Kementerian Pendidikan Malaysia dalam meningkatkan kualiti pendidikan (Kementerian Pendidikan Malaysia, 2014).

Selain itu, menurut Zuraidah (2010), antara faktor yang mempengaruhi pelaksanaan Komuniti Pembelajaran Profesional di sekolah menengah di Malaysia ialah latar belakang pengetua, guru-guru dan sekolah yang ingin membentuk budaya pembelajaran secara kolektif. Zuraidah (2017) menjelaskan bahawa budaya ini telah menunjukkan peranan dan tanggungjawab setiap individu yang terlibat dalam Komuniti Pembelajaran Profesional terhadap pembelajaran guru secara individu dan berpasukan bagi memastikan kesejahteraan semua warga sekolah). Oleh itu, Komuniti Pembelajaran Profesional menyebabkan guru-guru berasa mereka berjaya membina sistem sokongan dan belajar memperbaiki kelemahan.

Seterusnya, menurut Dima (2016) Komuniti Pembelajaran Profesional menggalakkan perkongsian ilmu dalam masyarakat dan pelaksanaan pelbagai aktiviti susulan seperti perjumpaan mingguan dapat menyemai semangat kerjasama selain membantu guru membina sikap positif dalam diri sebagai pendidik. Malahan, Nurul Syafinaz dan Noraini (2018) mendapati 69.23 peratus ( 9 daripada 13 sekolah) yang dikaji di daerah Besut, Terengganu mampu membudayakan Komuniti Pembelajaran Profesional dan memberikan impak positif kepada guru-guru sama ada dalam aspek kesediaan mengajar mahupun aspek intrapersonal dan interpersonal guru-guru melalui sifat keterbukaan kepada amalan perkongsian. Pendek kata, penyertaan dalam Komuniti Pembelajaran 
Profesional akan membaiki amalan pengajaran guru dan meningkatkan pencapaian murid (Doğan \& Adam, 2018).

Selain itu, Kin, Kareem dan Musa (2019) dalam kajian terhadap Komuniti Pembelajaran Profesional, mendapati tahap pelaksanaan komuniti pembelajaran profesional di sekolah rendah jenis kebangsaan cina (SJKC) adalah agak baik sahaja dalam semua dimensi. Menurut Kin et al. (2019), hal ini dapat dikaitkan dengan program pembangunan profesional berkaitan Komuniti Pembelajaran Profesional yang ditawarkan oleh Kementerian Pendidikan Malaysia kurang berkesan.

Dalam kajian lain, dapatan Tai dan Omar (2019) terhadap perbandingan pengamalan Komuniti Pembelajaran Profesional di sekolah menengah kebangsaan dan sekolah menengah berasrama di Semenanjung Malaysia menunjukkan kedua-dua jenis sekolah ini juga mencapai tahap agak baik sahaja. Selain itu, menurut Tai dan Omar (2019), keduadua jenis sekolah ini juga mempraktikkan Komuniti Pembelajaran Profesional secara lebih kerap dan menunjukkan prestasi yang agak memuaskan. Malahan, dapatan kajian Tai dan Omar (2021) di sekolah menengah di Malaysia konsisten menunjukkan bahawa pengamalan Komuniti Pembelajaran Profesional adalah agak kerap dan agak memuaskan sahaja. Sehubungan itu, tahap pengamalan Komuniti Pembelajaran Profesional di sekolah di Malaysia perlu ditingkatkan dengan membuat penambahbaikan. Malahan, dapatan kajian Kareem et al. (2019) berkaitan perbandingan amalan Komuniti Pembelajaran Profesional di sekolah menengah kebangsaan dan sekolah menengah agama di Semenanjung Malaysia, menunjukkan tahap pengamalan yang agak baik sahaja. Guruguru di kedua-dua jenis sekolah tersebut juga mempraktikkan Komuniti Pembelajaran Profesional agak kerap sahaja dengan prestasi yang agak memuaskan.

Di samping itu, dapatan kajian oleh Siti Nafsiah et al. (2020) menunjukkan sekolah berprestasi tinggi, sekolah transformasi dan sekolah amanah memberikan perhatian pada budaya kolaboratif dalam menjayakan amalan Komuniti Pembelajaran Profesional. Malahan, Komuniti Pembelajaran Profesional menyebabkan guru-guru bekerjasama antara satu sama lain dalam menjalankan program di sekolah bagi meningkatkan pengajaran dan pembelajaran murid.

Kesimpulannya, Komuniti Pembelajaran Profesional adalah tentang perubahan yang dibawa dalam pendidikan khususnya dalam mewujudkan sekolah yang berkesan, peningkatan pembangunan profesionalisme guru dan pencapaian murid. Pelbagai pendekatan baharu dilakukan untuk penambahbaikan guru secara profesional dengan mewujudkan budaya pembelajaran sepanjang hayat. Malahan, penambahbaikan melalui Komuniti Pembelajaran Profesional tidak lagi terhad kepada pencapaian akademik tetapi turut melibatkan pembangunan secara menyeluruh kepada warga sekolah. Peranan pengetua sekolah turut ditekankan dalam pembudayaan Komuniti Pembelajaran Profesional atas sokongan dan komitmen yang diberikan dalam menjayakan Komuniti Pembelajaran Profesional. Setiap dimensi dalam Komuniti Pembelajaran Profesional juga berperanan utama kepada pembentukan amalan Komuniti Pembelajaran Profesional kerana setiap dimensi dalam Komuniti Pembelajaran Profesional menggerakkan setiap ahli komuniti untuk terus belajar secara konsisten, membuat perkongsian ilmu dan pengalaman. Pendek kata, Komuniti Pembelajaran Profesional memerlukan pengetua, guru dan staf sokongan untuk terus belajar bersama-sama bagi memastikan penambahbaikan berterusan berlaku demi kemajuan sekolah dan pencapaian murid. 


\section{Objektif Kajian}

Kajian tinjauan ini bertujuan untuk mengenal pasti tahap Komuniti Pembelajaran Profesional dan tahap setiap dimensi Komuniti Pembelajaran Profesional di sekolah menengah kebangsaan di Malaysia.

\section{Metod kajian}

Kajian ini menggunakan pendekatan kuantitatif yang mana data dianalisis menggunakan perisian Statistical Package for Social Sciences (SPSS) versi 23. Data deskriptif yang diperoleh adalah berkaitan min dan sisihan piawai sahaja.

\subsection{Kaedah Persampelan}

Kajian ini menggunakan kaedah persampelan berstrata tidak berkadaran. Sampel berjumlah 702 orang yang terdiri daripada guru sekolah menengah kebangsaan di 13 buah negeri dan tiga Wilayah Persekutuan dilibatkan. Sebanyak 80 buah sekolah terlibat dalam kajian ini.

\subsection{Instrumen Kajian}

Kajian ini menggunakan instrumen Komuniti Pembelajaran Profesional yang dibangunkan oleh Tai, Omar dan Ghouri (2018). Instrumen ini mengandungi 44 item dan terdiri daripada lapan dimensi utama iaitu, i) norma dan visi utama (enam item), ii) komitmen dan sokongan pengetua (enam item), iii) sokongan berstruktur (5 item), iv) persefahaman dan kepercayaan rakan sekerja (lima item), v) pembelajaran kolaboratif (enam item), vi) dialog reflektif (enam item), vii) inkuiri kolektif (lima item) dan viii) sokongan luar (lima item).

\subsection{Kajian Rintis}

Kajian rintis telah dijalankan terhadap instrumen ini untuk memastikan kesahan dan kebolehpercayaan item. Antara kaedah yang digunakan ialah i) ulasan penyelia, ii) verifikasi daripada panel pakar bertauliah, iii) temu bual, iv) penilaian kejelasan item dan v) penilaian kebolehpercayaan konsistensi dalaman.

\subsection{Kerangka Kajian}

Kerangka kajian ini adalah berdasarkan model Komuniti Pembelajaran Profesional yang dibangunkan oleh Tai et al. (2018). Model Komuniti Pembelajaran Profesional dibangunkan oleh Tai et al. (2018) melalui kajian mereka'Developing a Preliminary Model on Profesional Learning Community in Malaysian Secondary School'. Menurut Tai et al. (2018), Komuniti Pembelajaran Profesional merujuk pada amalan kolaboratif yang dilakukan oleh komuniti sekolah ke arah mewujudkan persekitaran pembelajaran yang kondusif, peningkatan kompetensi guru dan pencapaian murid. Model Komuniti Pembelajaran Profesional Tai et al. (2018) berfokus pada lapan dimensi utama iaitu i) norma dan visi bersama, ii) komitmen dan sokongan pengetua sekolah, iii) sokongan berstruktur, iv) persefahaman dan kepercayaan rakan sekerja, v) pembelajaran kolaboratif, vi) dialog reflektif, vii) inkuiri kolektif dan viii) sistem sokongan luar seperti dalam Rajah 1. 
Rajah 1 : Kerangka Kajian

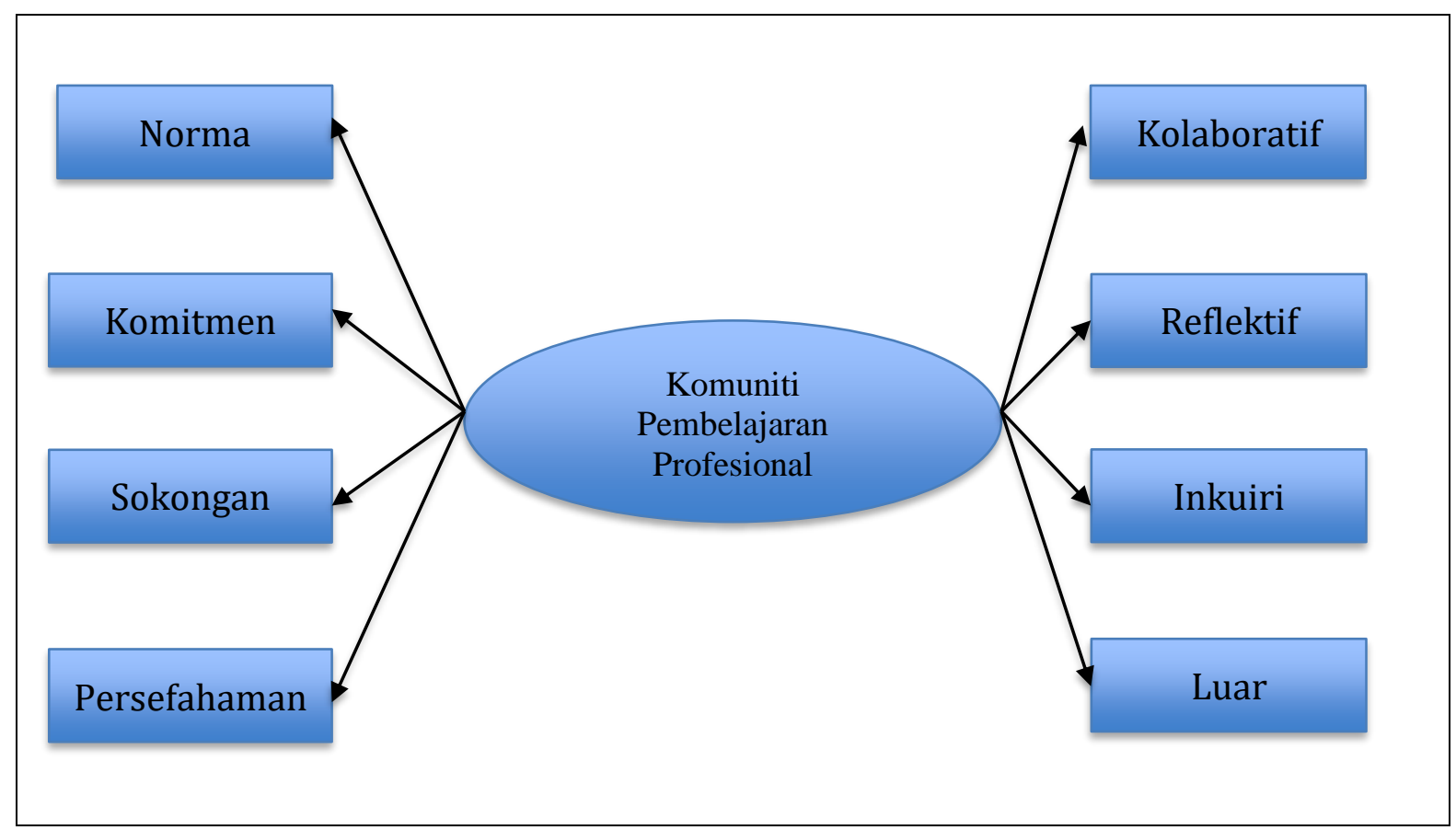

Nota: Norma=Norma dan Visi Bersama; Komitmen=Komitmen dan Sokongan; Sokongan=Sokongan Berstruktur; Persefahaman=Persefahaman dan Kepercayaan; Kolaboratif=Pembelajaran Kolaboratif; Reflektif=Dialog Reflektif; Inkuiri=Inkuri Kolektif; Luar=Sokongan Luar

\section{Hasil Kajian}

Analisis deskriptif min dan sisihan piawai digunakan untuk mengenal pasti tahap Komuniti Pembelajaran Profesional dan tahap setiap dimensi Komuniti Pembelajaran Profesional. Jadual skor min oleh Nunally dan Bernstein (1994) digunakan untuk menginterpretasikan tahap Komuniti Pembelajaran Profesional berdasarkan analisis data yang dijalankan. Menurut Nunally dan Bernstein (1994), terdapat empat tahap skor yang utama iaitu tahap rendah $(1.00-2.00)$, tahap sederhana rendah $(2.01-3.00)$, tahap sederhana tinggi $(3.01-4.00)$ dan tahap tinggi (4.01 - 5.00). Jadual interpretasi skor min adalah seperti dalam Jadual 1.

Jadual 1: Interpretasi Skor Min

\begin{tabular}{ll}
\hline Min & Interpretasi \\
\hline $1.00-2.00$ & Rendah \\
$2.01-3.00$ & Sederhana rendah \\
$3.01-4.00$ & Sederhana tinggi \\
$4.01-5.00$ & Tinggi \\
\hline
\end{tabular}

Sumber: Nunally dan Bernstein (1994)

Analisis yang dijalankan menunjukkan tahap Komuniti Pembelajaran Profesional di sekolah menengah kebangsaan di Malaysia adalah tinggi dengan nilai skor min yang diperoleh ialah 4.64 seperti yang ditunjukkan dalam Jadual 2. Ini membuktikan Komuniti Pembelajaran Profesional merupakan satu model matlamat bersama komuniti sekolah untuk menggalakkan kerjasama dalam kalangan guru dengan mewujudkan budaya profesional kolaboratif. Komuniti Pembelajaran Profesional menawarkan infrastruktur yang membentuk budaya dan sokongan yang diperlukan untuk mencapai keberhasilan 
yang ketara dalam pengajaran dan pembelajaran serta membantu guru menjadi lebih berkesan dalam komitmen mereka terhadap murid.

Berdasarkan Jadual 2, keseluruhan skor min untuk dimensi Komuniti Pembelajaran Profesional menunjukkan tahap yang tinggi. Skor min untuk dimensi norma dan visi bersama ialah 4.69. Ini menjelaskan bahawa komuniti sekolah mengamalkan perkongsian visi terutama berkaitan pembelajaran murid dan keberkesanan sekolah bagi mencapai visi yang dikehendaki. Sementara skor min untuk dimensi sokongan dan komitmen pengetua juga mencatatkan tahap yang tinggi dengan nilai 4.69. Keadaan ini menunjukkan pengetua memberi sokongan dan komitmen terhadap pembangunan dan penambahbaikan Komuniti Pembelajaran Profesional di sekolah selain mengambil tindakan optimum untuk menghadapi sebarang cabaran yang wujud.

Jadual 2: Min dan Sisihan Piawai Komuniti Pembelajaran Profesional

\begin{tabular}{lccc}
\hline Konstruk / Dimensi & Min & Sisihan Piawai & Tahap \\
\hline $\begin{array}{l}\text { Komuniti } \\
\text { PembelajaranProfesional }\end{array}$ & 4.64 & 0.46 & Tinggi \\
$\begin{array}{l}\text { Norma dan Visi Bersama } \\
\text { Komitmen dan Sokongan }\end{array}$ & 4.69 & 0.56 & Tinggi \\
$\begin{array}{l}\text { Pengetua } \\
\text { Sokongan Berstruktur }\end{array}$ & 4.69 & 0.67 & Tinggi \\
$\begin{array}{l}\text { Persefahaman dan } \\
\text { Kepercayaan Rakan Sekerja }\end{array}$ & 4.75 & 0.62 & Tinggi \\
$\begin{array}{l}\text { Pembelajaran Kolaboratif } \\
\begin{array}{l}\text { Dialog Reflektif } \\
\text { Inkuiri Kolektif }\end{array}\end{array}$ & 4.82 & 0.58 & Tinggi \\
Sokongan Luar & 4.60 & 0.56 & Tinggi \\
\hline
\end{tabular}

Manakala skor min untuk dimensi ketiga turut menunjukkan nilai yang tinggi iaitu 4.47 (Jadual 2). Hal ini menjelaskan bahawa sistem pengurusan, prosedur dan polisi menyokong pembangunan dan penambahbaikan Komuniti Pembelajaran Profesional dari segi pengurusan masa, ruang, kemudahan, sumber serta peruntukan dana. Dengan itu, keyakinan diri guru menjadi lebih tinggi, bersemangat dan komited untuk melaksanakan aktiviti Komuniti Pembelajaran Profesional kerana mendapat sokongan dalam aspek kewangan. Skor min untuk dimensi keempat iaitu persefahaman dan kepercayaan rakan sekerja ialah 4.75 (Jadual 2). Tahap yang pengamalan yang tinggi ini menunjukkan bahawa warga sekolah membina persefahaman, saling menghormati, percaya, sedar dan prihatin terhadap usaha untuk memudahkan penyelesaian masalah, mengambil keputusan dan menggalakkan perubahan.

Guru-guru di sekolah menengah kebangsaan di Malaysia juga mengamalkan dimensi kelima iaitu pembelajaran kolaboratif pada tahap yang tinggi. Nilai skor min yang didapati ialah 4.82 (Jadual 2). Ini menunjukkan bahawa guru-guru mempraktikkan pembelajaran 
kolaboratif dengan sentiasa berkongsi maklumat, sumber dan perancangan, penyelesaian masalah, pengukuhan amalan pengajaran dan membaiki pembelajaran pelajar. Sehubungan itu, menurut Bantwini (2019) pembelajaran kolaboratif merupakan elemen yang berkesan dalam membangunkan profesionalisme guru dan peningkatan pembelajaran murid ke arah penambahbaikan sekolah. Seterusnya skor min bagi dimensi keenam Komuniti Pembelajaran Profesional iaitu dialog reflektif menunjukkan tahap yang tinggi dengan nilai 4.60 (Jadual 2). Ini menunjukkan guru-guru menjalankan dialog jurnal atau menyertai perbualan refleksi secara berkumpulan atau berpasangan dengan aktif bagi membantu guru mendapatkan pandangan baharu tentang amalan pengajaran dan perspektif yang kerap diguna dalam suasana yang saling menyokong.

Tahap amalan guru-guru untuk dimensi ketujuh iaitu inkuiri kolektif juga tinggi dengan nilai min 4.72 (Jadual 2). Hal ini membuktikan peranan yang dimainkan oleh staf dan komuniti sekolah untuk membentuk perkongsian maklumat bagi menguji secara sistematik dan kolektif tentang amalan dan kesan Pendidikan. Akhir sekali, dimensi kelapan Komuniti Pembelajaran Profesional iaitu sokongan luar juga seperti dimensi yang lain menunjukkan tahap yang tinggi iaitu skor min 4.29 (Jadual 2). Situasi ini mungkin disebabkan terdapat usaha untuk membaiki pencapaian murid dan sekolah melalui kolaboratif bersama keluarga, masyarakat setempat, Pejabat Pendidikan Daerah dan Jabatan Pendidikan Negeri ke arah mencapai visi serta misi sekolah.

\section{Perbincangan Kajian}

Dapatan kajian ini terhadap tahap Komuniti Pembelajaran Profesional menunjukkan pengamalan Komuniti Pembelajaran Profesional yang tinggi oleh guru di sekolah menengah kebangsaan di Malaysia adalah tinggi. Menurut Zuraidah dan Rahimah (2009) tahap tinggi ini dipengaruhi oleh jalinan hubungan kolaboratif dalam kalangan warga sekolah khususnya ketika melaksanakan pelbagai aktiviti dan program untuk meningkatkan prestasi murid. Namun demikian dapatan kajian oleh Kareem et al. (2019) terhadap amalan Komuniti Pembelajaran Profesional di sekolah menengah agama di semenanjung Malaysia menunjukkan tahap Komuniti Pembelajaran Profesional yang agak baik sahaja.

Selain itu, dapatan kajian menunjukkan dimensi norma dan visi bersama mempunyai tahap yang tinggi dan membuktikan bahawa guru-guru dan komuniti sekolah berkongsi visi tentang pembelajaran murid, pedagogi, prestasi dan keberkesanan sekolah untuk mencapai matlamat Komuniti Pembelajaran Profesional (Ahmad Marzuki Mohamad, Zairus Norsiah Azahar, Azhar Muhammad \& Wan Hassan Wan Embong, 2015). Dalam kata lain, sekiranya semua warga sekolah bekerja secara kolaboratif dan memikul tanggungjawab bersama dalam Komuniti Pembelajaran Profesional, penambahbaikan sekolah dapat dilakukan secara berkesan (Bolam et al., 2005; Stoll et al., 2006)

Malahan, tahap pengamalan dimensi komitmen dan sokongan pengetua juga tinggi. Kebanyakan kajian secara konsisten menunjukkan bahawa sokongan dan komitmen pengetua adalah salah satu elemen terpenting dalam pembangunan Komuniti Pembelajaran Profesional (Hallinger, Lee, \& Ko, 2014; Harris \& Jones, 2010; Kilbane, 2009). Sehubungan itu, sebagai tanda komitmen dan sokongan, pengetua perlu sentiasa memberi sokongan emosi kepada guru apabila mereka berhadapan dengan masalah pembelajaran murid. Menurut Khalip et al. (2014) pemimpin sekolah harus memberi sokongan moral kepada guru bagi meningkatkan dan mengekalkan motivasi mereka. Pernyataan ini turut disokong oleh Ling dan Othman (2018) bahawa sokongan emosi 
merupakan bantuan penting untuk meningkatkan motivasi guru ketika mereka berhadapan dengan masalah berkaitan pembelajaran murid.

Tahap pengamalan dimensi sokongan berstruktur yang tinggi juga membuktikan kemudahan sekolah mencukupi untuk berkolaboratif secara berterusan merentasi pelbagai peringkat organisasi (Tai \& Omar, 2019). Menurut Ahmad Marzuki et al. (2016) kemudahan sekolah yang kondusif dan mencukupi serta sistem komunikasi yang berkesan memberi kemudahan kepada guru untuk berbincang dan melakukan program pembelajaran pada bila-bila masa. Malahan, sekolah-sekolah yang mempunyai kelengkapan prasarana pendidikan memberi impak positif kepada corak amalan Komuniti Pembelajaran Profesional (Zuraidah, 2010).

Selain itu, tahap amalan dimensi persefahaman dan kepercayaan rakan sekerja yang tinggi juga menunjukkan guru dapat menyesuaikan diri dengan cara kerja rakan sejawat yang lain dengan pantas. Apabila penyesuaian berlaku, maka guru-guru dapat bekerjasama dalam satu pasukan dan mengelakkan sikap suka mengasingkan diri. Mengikut Rosnah et al. (2020), budaya mengasingkan diri sudah menjadi budaya tradisi di kebanyakan sekolah dan merupakan kekangan dalan mewujudkan pendidikan yang berkualiti. Pembangunan profesional guru menjadi tidak efektif apabila guru-guru belajar secara individu selain terpisah daripada rakan sejawatan tanpa maklum balas dan tindakan susulan (Akinyemi et al., 2019). Menurut Trust dan Horrocks (2016) tindakan mengasingkan diri dalam kalangan guru di sekolah dapat diatasi melalui kerjasama dan berkongsi idea sesama rakan sekerja. Pendek kata, penyesuaian diri dengan rakan sekerja penting untuk meningkatkan keyakinan diri kepada guru dalam Komuniti Pembelajaran Profesional mahupun melaksanakan pembelajaran dalam tugas harian di sekolah (Achinstein \& Athanases, 2005).

Seterusnya tahap pengamalan dimensi pembelajaran kolaboratif yang tinggi turut menunjukkan guru-guru di sekolah sentiasa bertukar-tukar bahan pengajaran untuk memudahkan pembelajaran murid yang berkesan. Guru mendapatkan bahan, idea serta teknik melalui perkongsian dengan rakan sejawat untuk membantu meningkatkan pencapaian murid (Dufour, 2004). Dalam kata lain, perkongsian amalan terbaik pengajaran memperkayakan guru dengan pelbagai pengetahuan, kaedah dan pengalaman untuk meningkatkan proses pengajaran dan pemudahcaraan di dalam kelas dan seterusnya meningkatkan prestasi murid.

Tahap amalan dimensi dialog reflektif yang tinggi juga menunjukkan guru-guru berkongsi idea inovatif dan mencuba kaedah baharu untuk meningkatkan kaedah pengajaran. Mengikut Dufour (2004), dialog reflektif berkaitan pembelajaran murid merupakan amalan kolaboratif yang penting untuk membudayakan Komuniti Pembelajaran Profesional di sekolah. Bukan itu sahaja, para pendidik juga boleh menyesuaikan strategi pengajaran mereka selepas berlakunya dialog reflektif. Menurut Dima (2016), perkongsian ilmu dan perbincangan dalam Komuniti Pembelajaran Profesional secara terancang dan sistematik mendorong guru untuk membuat pengubahsuaian teknik dan kaedah lama supaya selari dengan pendidikan terkini.

Di samping itu, tahap amalan dimensi inkuri kolektif yang tinggi mengesahkan bahawa guru-guru cenderung mencuba kaedah dan intervensi baharu untuk meningkatkan pembelajaran murid. Menurut Zuraidah (2010), amalan inkuiri kolektif membolehkan guru merancang, menyelesaikan masalah dan mengenal pasti keperluan pembelajaran murid. Melalui inkuiri kolektif juga, guru mencari pengetahuan dan meningkatkan 
kemahiran untuk diaplikasikan dalam pengajaran dan pembelajaran (Wieczorek \& Lear, 2018). Seterusnya, guru akan mengetahui kaedah dan strategi untuk meningkatkan pembelajaran murid secara berkesan (Anis Salwa \& Siti Noor, 2018).

Akhir sekali, tahap amalan yang tinggi untuk dimensi sokongan luar juga membuktikan bahawa wujudnya pelibatan Persatuan Ibu Bapa dan Guru (PIBG) secara aktif dalam mempromosikan tanggungjawab bersama demi pembelajaran murid. Hubungan yang baik antara sekolah dengan ibu bapa dapat memberi pengalaman pembelajaran bermakna dan memberi kesan positif terhadap pembelajaran murid (Bahagian Pembangunan Kurikulum, 2016). Menurut Halimah, Eow dan Chuah (2014), ibu bapa, masyarakat setempat, agensi kerajaan, agensi swasta dan NGO memainkan peranan yang sangat penting dalam menyokong pembangunan dan pelaksanaan Komuniti Pembelajaran Profesional yang seterusnya dapat meningkatkan pencapaian sekolah secara berterusan.

\section{Kesimpulan}

Komuniti Pembelajaran Profesional merupakan inisiatif untuk membantu guru dalam pembelajaran yang dapat menyumbang kepada peningkatan pencapaian murid. Pembudayaan Komuniti pembelajaran Profesional di sekolah dapat menggalakkan dan mengembangkan nilai-nilai pembelajaran melalui proses kolaboratif yang menekankan pembelajaran secara dinamik dalam kalangan guru, murid, pengetua, ibu bapa dan masyarakat. Secara ringkas Komuniti Pembelajaran Profesional merupakan agen untuk meningkatkan kemahiran profesionalisme guru dan pencapaian murid melalui aktiviti pembelajaran secara kolaboratif yang berkesan. Dalam kata lain, Komuniti Pembelajaran Profesional boleh diaplikasikan oleh pengetua dalam usaha untuk meningkatkan profesionalisme dalam kalangan guru, meningkatkan prestasi sekolah dan meningkatkan pencapaian murid secara menyeluruh di sekolah menengah kebangsaan di Malaysia.

\section{Penghargaan (Acknowledgement)}

Sekalung penghargaan kepada penyelia utama, responden, pengulas dan editor yang terlibat atas komen membina yang diberikan terhadap versi asal artikel ini.

\section{Kewangan (Funding)}

Kajian dan penerbitan ini tidak menerima sebarang tajaan atau bantuan kewangan daripada mana-mana pihak.

\section{Konflik Kepentingan (Conflict of Interests)}

Penulis tidak berpotensi dan tidak mempunyai konflik kepentingan terhadap penyelidikan, penulisan dan/atau penerbitan artikel ini.

\section{Rujukan}

Akinyemi, Adeola Folasade; Rembe, Symphorosa; Shumba, Jenny \& Adewumi, Toyin Mary and Szameitat, Andrea. (2019). Collaboration and mutual support as processes established by communities of practice to improve continuing professional teachers' 
development in high schools. Cogent Education, 6(1), 1685446. DOI: 10.1080/2331186X.2019.1685446.

Ahmad Marzuki Mohamad, Zairus Norsiah Azahar, Azhar Muhammad \& Wan Hassan Wan Embong. 2015. Komuniti Pembelajaran Profesional: Aplikasi Dalam Kalangan Komuniti SMKA Di Negeri Johor. International Journal of Islamic Studies and Arabic Language Education, 2(1), 11-22.

Anis Salwa Abdullah, \& Siti Noor Ismail. (2018). Interaksi Kepimpinan Perkongsian dan Kepimpinan Sahih Guru Besar Terhadap Motivasi dan Tekanan Kerja Guru. Jurnal Kepimpinan Pendidikan, 5(1), 16-28.

Bahagian Pembangunan Kurikulum. (2016). Dokumen Standard Kurikulum dan Pentaksiran Pendidikan Prasekolah. Kementerian Pendidikan Malaysia.

Achinstein, B., \& Athanases, S. (2005). Focusing New Teachers on Diversity and Equity: Toward a Knowledge Base for Mentors. Teaching and Teacher Education 21(7), 84362.

Bolam, R., McMahon, A., Stoll, L., Thomas, S., Wallace, M., Greenwood, A., Hawkey, K., Ingram, M., Atkinson, A. \& Smith, M. (2005). Creating and Sustaining Effective Professional Learning Communities. Research Report 637. London: DfES and University of Bristol.

Bantwini, B. D. (2019). Developing A Culture of Collaboration and Learning Among Natural Science Teachers as A Continuous Professional Development Approach in A Provincein South Africa. Teacher Development, 23(2), 213-232. DOI: 10.1080/13664530.2018.153349.

Dima Mazlina@Siti Aishah Abu Bakar. (2016). Pelaksanaan Komuniti Pembelajaran Profesional (Kpp) Untuk Peningkatan Kemahiran Guru Bahasa Melayu Mengajar Penulisan Karangan. Jurnal Kurikulum \& Pengajaran Asia Pasifik, 4(3).

Doğan, S. \& Adams, A. (2018). Effect of professional learning communities on teachers and students. reporting updated results and raising questions about research design. School Effectiveness and School Improvement 29(4), 1-26. DOI: 10.1080/09243453.2018.1500921

DuFour, R. (2004). What is a professional learning community? Educational Leadership, 61(8), 6-11.

DuFour, R., DuFour, R., Eaker, R., \& Many, T. (2006). Learning by doing: A handbook for Professional Learning Communities at Work (1st ed.). Bloomington, IN: Solution Tree Press.

Hallinger, P., Lee, Moosung., \& Ko, James. (2014). Exploring the Impact of SchoolPrincipals on Teacher Professional Communities in Hong Kong. Leadership and Policy in Schools, 13(3), 229-259.

Halimah, B. A. M., Eow, Y. L., \& Chuah, B. E. (2014). Model pendidikan berkualiti 6S. Jurnal Pendidikan MPSM, (1), 145-164.

Harris, A. \& Jones, M. (2010). Professional Learning Communities and System Improvement. Improving School, 13(2), 172-181. DOI: $10.1177 / 1365480210376487$

Hord, S. M. (1997). Professional learning communities: Communities of continuous inquiry and improvement. Austin, Texas: Southwest Educational Development Laboratory.

Kareem, O. A., Kin, T. M., Musa, K. bin, \& Ghouri, A. M. (2019). Professional Learning Communities in Peninsular Malaysia: Comparing Day Secondary School and National Religious Secondary School. International Journal of Academic Research in Progressive Education and Development, 8(2), 379- 397.

Khalip Musa, Hamidah Yusof, Jamal@Nordin Yunus, Suriani Abdul Hamid. (2014). Kepimpinan Transformasional Pengetua: Perbandingan Antara Sekolah Menengah Awam dan Swasta Cemerlang. Management Research Journal, 3, 120-139. 
Kilbane, J.F. (2009). Factors in Sustaining Professional Learning Community. NASSP Bulletin, 93(3), 184-205. Doi:10.1177/0192636509358923

Kin, T. M., Kareem, O. A., \& Musa, K. bin. (2019). Examining Professional Learning Communities in National-Type Chinese Primary Schools in Perak, Malaysia. International Journal of Academic Research in Progressive Education and Development, 8(2), 418-438.

Kementerian Pendidikan Malaysia. (2012). Laporan Awal Pelan Pendidikan Awal 20132025. Putrajaya: Kementerian Pendidikan Malaysia.

Kementerian Pendidikan Malaysia. (2014). Laporan awal Pelan Pembangunan Pendidikan Malaysia. Putrajaya: Kementerian Pendidikan Malaysia.

Kementerian Pendidikan Malaysia. (2015). Laporan Tahunan 2015 Pelan Pembangunan Pendidikan Malaysia. Putrajaya: Kementerian Pendidikan Malaysia.

King, M. Bruce \& Newmann, Fred M. (2001). Building School Capacity Through Professional Development: Conceptual and Empirical Considerations. The International Journal of Educational Management. 15(2), 86-93.

Ling, C. J., \& Othman, N. (2018). Amalan Penyeliaan dan Hubungannya Dalam Meningkatkan Kualiti Pengajaran Guru. International Journal of Education, Psychology and Counselling, 3(22), 28-48.

Lomos, C., Hofman, R. H., \& Bosker, R. J. (2011). The Relationship Between Departments as Professional Communities And Student Achievement in Secondary Schools. Teaching and Teacher Education,27(4), 722731. https://doi.org/10.1016/j.tate.2010.12.003

Louis, K. S., Marks, H. M., \& Kruse, S. (1996). Teachers' Professional Community In Restructuring Schools. American Educational Research Journal, 33(4), 757798. https://doi.org/10.2307/1163415

Mitchell, C., \& Sackney, L. (2000). Profound Improvement: Building Capacity for A Learning Community. Lisse,The Netherlands: Swets \& Zeitlinger

Nunally, J., \& Bernstein, I. (1994). Psychometric Theory. Edisi ke-3. New York: McGraw Hill. Nurul Syafinaz Ishak \& Noraini Ibrahim. (2018). Peranan SISC+ dalam pembudayaan Profesional Learning Community (PLC) di sekolah. Prosiding Seminar Darulaman 2018 Peringkat Kebangsaan, 452-459.

Rosnah Ishak, Kamarudin Ismail \& Siti Hajar Kamaruddin. (2020). Professional learning communities in Malaysian schools: A contemporary literature review. Universal Journal of Educational Research, 8(4), 1535-1541. https://doi.org/10.13189/ujer.2020.080447

Senge, P.M. (1990). The fifth discipline: The art and pratice of the learning organization. New York: Doubleday.

Siti Nafsiah Ismail, Zuraidah Abdullah, Abdul Jalil Othman, \& Salwati Shafie. (2018). Amalan Komuniti Pembelajaran Profesional Dalam Kalangan Guru Bahasa Melayu di Selangor. Jurnal Kepimpinan Pendidikan, 5(4).

Stoll L, Bolam R, McMahon A, Wallace M \& Thomas S. (2006). Professional learning communities: A review of the literature. Journal of Educational Change, 7(4), 221258.

Tai, M. K., Omar, A. K., \& Ghouri, A. M. (2018). Developing a preliminary model on professional learning community in Malaysian secondary school (Unpublished research report which was funded by Fundamental Research Grant Scheme [Code: 2017-0196-107-01], Ministry of Higher Education Malaysia). Sultan Idris Education University, Perak Darul Ridzuan, Malaysia

Tai, M. K., \& Omar, A. K. (2019). Professional learning communities: A comparison study between Day Secondary School and Fully Residential Secondary School in Malaysia, 
International Journal of Academic Research in Progressive Education and Development, 8(2), 87-101.

Tai, M.K. \& Omar, A.K. (2021). Identifying factors contributing to the development and sustainability of professional learning communities in Malaysian secondary schools'. Int. J. Management in Education, 15(4), 337-361.

Toole, J.C. \& Louis, K.S. (2002). The Role of Professional Learning Communities in International Education. In K. Leithwood \& P. Hallinger (eds), Second International Handbook of Educational Leadership and Administration.

Trust, T., \& Horrocks, B. (2016). 'I Never Feel Alone in My Classroom': Teacher Professional Growth Within a Blended Community of Practice. Professional Development in Education, 43(4), 1-21.

Wieczorek, D., \& Lear, J. (2018). Building the "Bridge": Teacher Leadership for Learning and Distributed. International Journal of Teacher Leadership, 9(2), 22-46.

Zhang, Jia \& Sun, Yuantao. (2019). Investigating the effects of professional learning communities on teacher commitment in China. Educational Studies, 46(6), 773-777 DOI: $10.1080 / 03055698.2019 .1651695$

Zuraidah Abdullah \& Rahimah Ahmad. (2009). Komuniti Pembelajaran Profesional: Satu Kajian Perbandingan Antara Sekolah Menengah Kebangsaan Harian Biasa Dan Sekolah Menengah Kebangsaan Anugerah Cemerlang 2007. Jurnal Administrasi Pendidikan, 10(2). https://doi.org/10.17509/jap.v10i2.6308.

Zuraidah Abdullah. (2010). Creating A Professional Learning Community: A Study of Malaysian Secondary Schools. Jurnal Manajemen Pendidikan, 2, 78-96.

Zuraidah Abdullah. (2017). Komuniti Pembelajaran Profesional di Malaysia : Amalan Penambaikan Sekolah (2nd ed.). Penerbit Universiti Malaya. 